\title{
Nuclear-follower foraging associations among Characiformes fishes and Potamotrygonidae rays in clean waters environments of Teles Pires and Xingu rivers basins, Midwest Brazil
}

\author{
Domingos Garrone Neto $^{1,3}$ \& Lucélia Nobre Carvalho ${ }^{2}$ \\ ${ }^{1}$ Laboratório de Pesquisa de Elasmobrânquios, Universidade Estadual Paulista, \\ Campus Experimental do Litoral, CEP 11330-900, São Vicente, SP, Brazil \\ ${ }^{2}$ Núcleo de Estudos de Biodiversidade da Amazônia Mato-grossense - NEBAM, \\ Instituto de Ciências Naturais, Humanas e Sociais - ICNHS, Universidade Federal do Mato Grosso - UFMT, \\ CEP 78557-267, Sinop, Mato Grosso, MT, Brazil \\ ${ }^{3}$ Corresponding author: Domingos Garrone Neto, e-mail: garroneneto@yahoo.com.
}

GARRONE NETO, D. \& CARVALHO, L.N. Nuclear-follower foraging associations among Characiformes fishes and Potamotrygonidae rays in clean waters environments of Teles Pires and Xingu rivers basins, Midwest Brazil. Biota Neotrop. 11(4): http://www.biotaneotropica.org.br/v11n4/en/abstract?shortcommunication+bn01511042011

\begin{abstract}
During under and overwater observations were recorded nuclear-follower foraging associations among three species of characiform fishes - Chalceus epakros, Hemiodus semitaeniatus and Hemiodus unimaculatus and a freshwater stingray species - Potamotrygon orbignyi - in the Teles Pires and Xingu rivers basins, Midwest Brazil. The teleost fishes were observed closely following the stingrays during the behavior of stirring the substrate to uncover invertebrates, which cause discrete sediment clouds. Apparently this sediment perturbation attracts the fishes that approached the foraging stingrays to feed on small preys and other food types exposed this way. This is a typical example of a commensal relationship in which one participant is benefited while the other is unaffected, and represents the second published record of nuclear-follower feeding association between potamotrygonid rays and teleost fishes, demonstrating the potential of naturalistic studies in discovering new interactions involving species of freshwater fish.

Keywords: following behavior, foraging habits, interespecific interactions, Characidae, Hemiodontidae, Amazon
\end{abstract} Basin.

GARRONE NETO, D. \& CARVALHO, L.N. Associações alimentares do tipo nuclear-seguidor entre peixes Characiformes e raias Potamotrygonidae em ambientes de águas límpidas das bacias dos rios Teles Pires e Xingu, Centro-Oeste do Brasil. Biota Neotrop. 11(4): http://www.biotaneotropica.org.br/v11n4/pt/abstract?shortcommunication+bn01511042011

Resumo: Por meio de observações sub e supra-aquáticas foram registradas associações alimentares do tipo nuclear-seguidor entre três espécies de peixes characiformes - Chalceus epakros, Hemiodus semitaeniatus e Hemiodus unimaculatus - e uma espécie de raia de água doce - Potamotrygon orbignyi - nas bacias dos rios Teles Pires e Xingu, no Centro-Oeste do Brasil. Os peixes teleósteos foram observados seguindo as raias quando estas revolviam o substrato à procura de invertebrados, formando discretas nuvens de sedimento. Essas situações atraíram os peixes que se aproximaram das raias para se alimentar de pequenas presas e outros tipos de alimentos expostos desta forma. Esse é um típico exemplo de relação comensal onde um participante é beneficiado enquanto o outro não é prejudicado e representa o segundo registro na literatura de associação alimentar do tipo nuclearseguidor entre raias potamotrigonídeas e peixes teleósteos, demonstrando o potencial de estudos naturalísticos para a descoberta de novas interações envolvendo espécies de peixes de água doce.

Palavras-chave: comportamento de seguidor, hábitos alimentares, interações interespecíficas, Characidae, Hemiodontidae, Bacia Amazônica. 


\section{Introduction}

The following behavior comprises one or a group of individuals that excavate or disturb the substrate while foraging, and one or more opportunistic species that capitalize on the small organisms and other food types displaced by the foraging activity of the former (Strand 1988, Lukoschek \& McCormick 2000). This type of interespecific interaction has been widely described to teleost fishes in marine environments (see Strand (1988) and Sazima et al. (2006) for overviews), although a few instances are reported from neotropical freshwater habitats that provide conditions for underwater observations (Sazima 1986, Baker \& Foster 1994, Casatti \& Castro 1998, Sabino \& Zuanon 1998, Sabino 1999, Carvalho et al. 2003a, Garrone Neto \& Sazima 2009a, Leitão et al. 2007, Teresa \& Carvalho 2008, Teresa et al. 2011).

In this study we aim to expand the data relating to this type of interaction, reporting the first nuclear-follower feeding association among species of mid waters characiform fishes Chalceus epakros Zanata \& Toledo-Piza, 2004 (Characidae),
Hemiodus semitaeniatus Kner, 1858 and Hemiodus unimaculatus (Bloch, 1794) (Hemiodontidae) - and freshwater stingrays Potamotrygon orbignyi (Castelnau, 1855) (Potamotrygonidae).

\section{Material and Methods}

During the dry seasons of 2009 and 2010 observations were conducted under and overwater in two lagoons and in a river located in the Teles Pires and Xingu rivers basins, in the north of Mato Grosso State, Midwest Brazil (Figure 1). The Ipawu Lagoon, one of the biggest natural lentic environments of the Upper Xingu River Basin (about $12^{\circ} 07^{\prime} \mathrm{S}$ and $53^{\circ} 25^{\prime} \mathrm{W}$ ), and the Tuatuari River, a tributary of Kuluene River situated in the headwaters of the Xingu River Basin (about $12^{\circ} 13^{\prime} \mathrm{S}$ and $53^{\circ} 22^{\prime} \mathrm{W}$ ), were located in the Xingu Indigenous Park. The Blue Lagoon, a marginal pond formed from a spring inside the forest that is positioned in the middle course of the Teles Pires River (about $9^{\circ} 06^{\prime} \mathrm{S}$ and $57^{\circ} 03^{\prime} \mathrm{W}$ ), is located in the Apiaká-Kayabi Indigenous Land. All places are situated in protect areas, in the ecotone between the Brazilian Savannah and
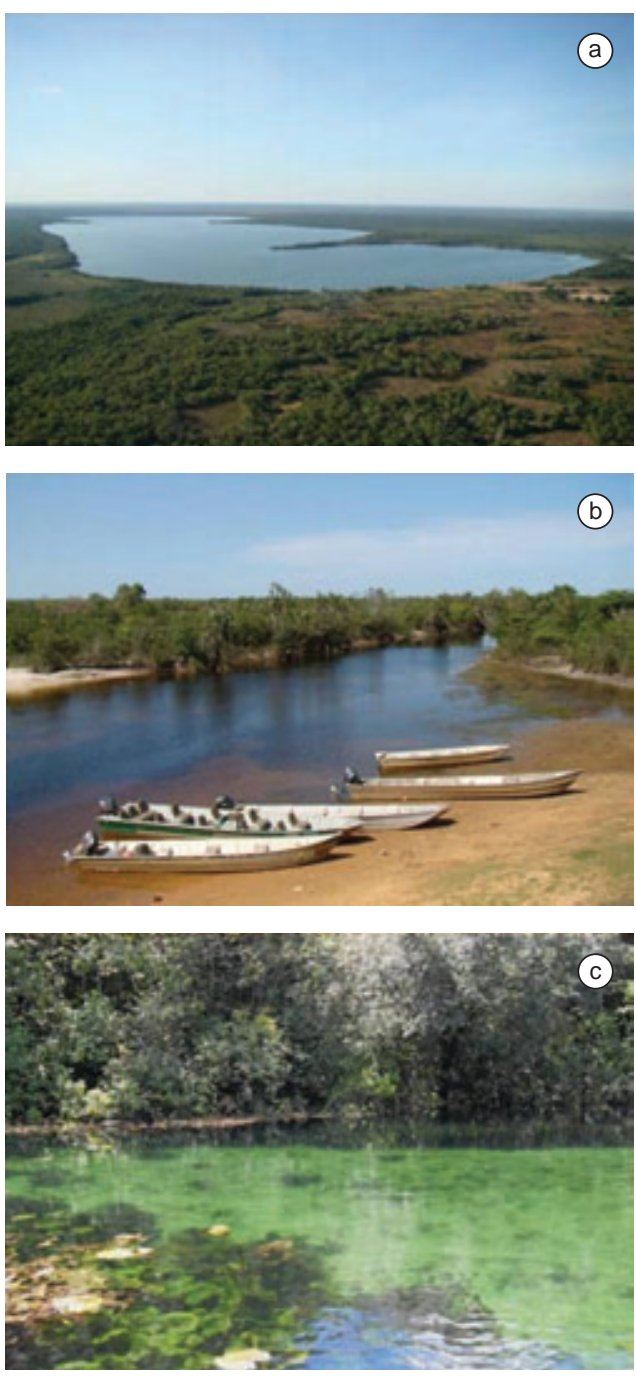
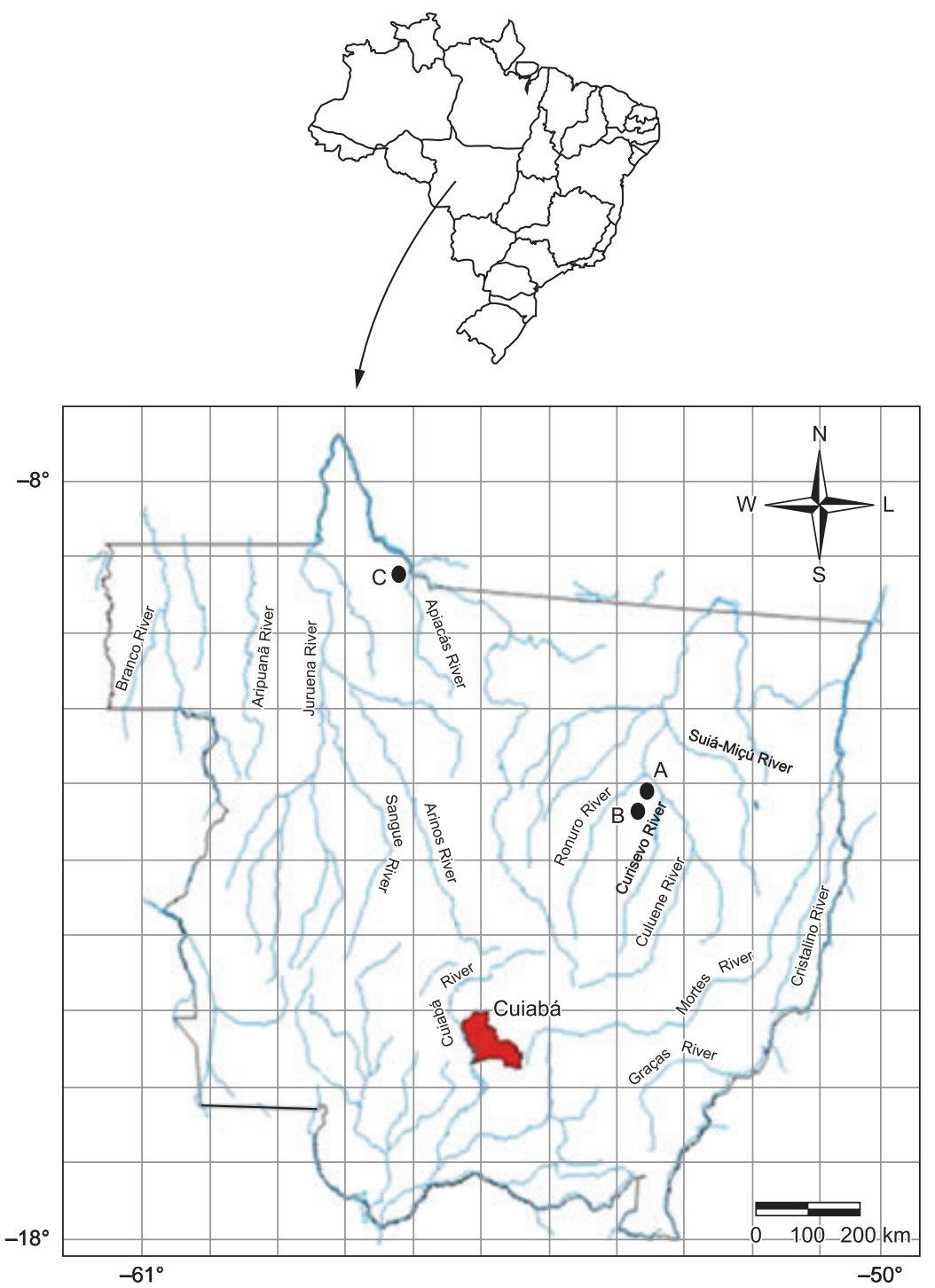

Figure 1. Study sites in the Teles Pires and Xingu rivers basins: a)Ipawu Lagoon , b) Tuatuari River, and c) Blue Lagoon. The area in red represents the municipality of Cuiabá, capital of the state of Mato Grosso, Midwest Brazil.

Figura 1. Locais de estudo nas bacias dos rios Teles Pires e Xingu: a) Lagoa Ipawu, b) Rio Tuatuari, e c) Lagoa Azul. A área em vermelho representa o município de Cuiabá, capital do estado do Mato Grosso, Centro-Oeste do Brasil. 
the Amazon Forest, and have very favorable conditions for diving, especially during drought periods.

"Ad libitum" and "behavior" sampling rules (Martin \& Bateson 1986) were used throughout snorkeling observational sessions (Sabino 1999), conducted at depths of 0.5 to $3 \mathrm{~m}$ (diurnal $=8$ hours; nocturnal $=3$ hours), and during observations conducted inside boats, at a distance of about 4-5 $\mathrm{m}$ of the animals (diurnal $=6$ hours; nocturnal $=4$ hours). Additionally, digital photographs were taken to check visual observations and one specimen of each of the four field-identified species were collected and stored in the fish collection of the Instituto Nacional de Pesquisas da Amazônia-INPA (voucherspecimens: C. epakros-INPA 35618; H. semitaeniatus-INPA 35619; H. unimaculatus-INPA 31006; P. orbignyi-INPA 35620) to enable future verification, especially with regard to $P$. orbignyi, a widespread stingray species that may require subdivision (Carvalho et al. 2003b).

\section{Results and Discussion}

The feeding associations among the characiform fishes as followers and $P$. orbignyi as nuclear were observed far way the banks $(2.5-4.5 \mathrm{~m}$; $\mathrm{SD}=1.4)$ and in areas without the presence of macrophytes. These associations were observed in four occasions: one involving individuals of C. epakros (10-15 cm of total length-TL), two of $H$. unimaculatus (14-20 cm TL) and one of H. semitaeniatus $(15-20 \mathrm{~cm} \mathrm{TL})$. All records were made during the evening, between 3:00 and 5:00 PM, on sand substrate and with full transparency of the water. For $C$. epakros and H. semitaeniatus the interaction with P. orbignyi was documented only in the Tuatuari River and in the Blue Lagoon, respectively. To $H$. unimaculatus the records were made in the Ipawu Lagoon and in the Tuatuari River.

In all cases the interactions started when solitary rays measuring $28-40 \mathrm{~cm}$ of disc width were moving and initiating their foraging activity, using the hunting tactic termed "undulate the disc and stir substrate" (Garrone Neto \& Sazima 2009b) to revolve the bottom to uncover hidden preys and forming discrete sediment clouds near it. This behavior attracted the characiform fishes that approached to the foraging rays and followed it from behind in shoals of five to eight individuals $(C$. epakros $=05 ; H$. semitaeniatus $=08$; $H$. unimaculatus $=06$ ), nipping eventual items revealed this way (Figure 2). The duration of these interactions varied between 40 to

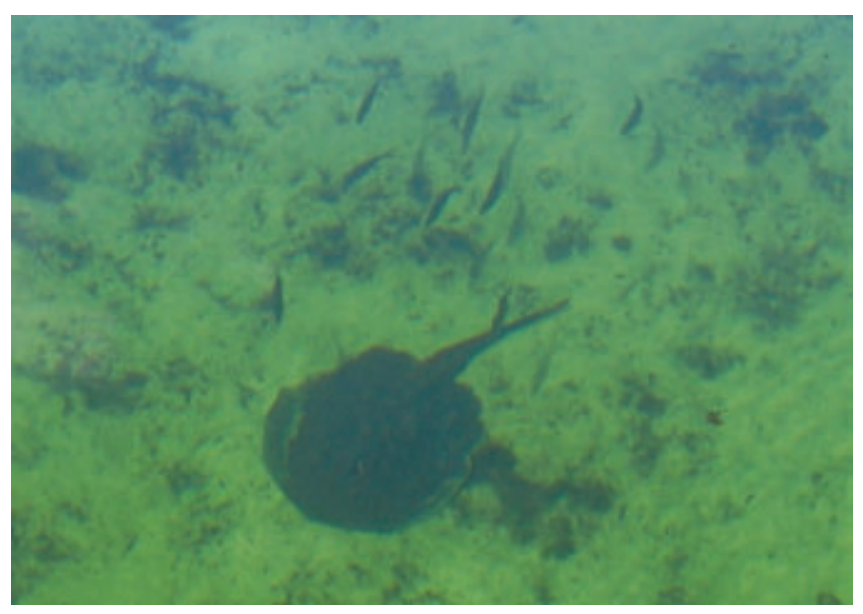

Figure 2. Feeding association among characiform fishes and a potamotrygonid stingray. It is possible to observe a shoal of Hemiodus semitaeniatus following a foraging individual of Potamotrygon orbignyi in a clear water lentic environment.

Figura 2. Associação alimentar entre peixes Characiformes e uma raia Potamotrygonidae. É possível observar um cardume de Hemiodus semitaeniatus seguindo um indivíduo de Potamotrygon orbignyi durante sua atividade alimentar em um ambiente de águas límpidas.
84 seconds $(x=60$ seconds; $S D=18.18)$ and ceased once the rays approached the macrophytes and riparian vegetation.

Although substrate disturbance is one of the most important predictors for the species acting as nuclear (Sazima et al. 2006, Krajewski 2009, Teresa et al. 2011) and tetras are opportunistic foragers (Sazima 1986, Teresa \& Carvalho 2008), a typical nuclearfollower feeding association and interactions of characiform fishes with potamotrigonid rays had not been described under natural conditions. The only record related to this subject was made by Garrone Neto \& Sazima (2009a), that reported feeding associations among two species of Potamotrygonidae and cichlids in a disturbed stretch of the Upper Paraná River, Southeastern Brazil.

These authors compared the cited interactions with following behavior, but considered it uncommon and transient, and not a typical nuclear-follower feeding association, since the teleost fishes species just approached to the rays while it were already stirring the substrate. They also observed that the interactions occurred in places with high sediment deposition (marginal ponds and dammed river portions with muddy bottom) and near the macrophytes, and that the cichlids did not followed the foraging rays when it moving away from the marginal vegetation, differently from the observed in the Ipawu Lagoon, in the Tuatuari River and in the Blue Lagoon.

The interactions among the insectivorous $C$. epakros and the herbivores $H$. semitaeniatus and H. unimaculatus (Dary 2010) with the carnivore $P$. orbignyi (Lasso et al. 1996, Rincon 2006) demonstrates the versatility of these characiform species to explore the environmental resources and reinforce the opportunistic feeding habits attributed to these fishes (Sazima 1986, Dary 2010). Furthermore, these records represents the first register in the literature of a typical nuclear-follower feeding association between freshwater stingrays and teleost fishes, and demonstrates the importance of naturalistic studies using underwater observations for the discovery of complex relationships that occur in freshwater ecosystems and which are still unknown or poorly documented.

As punctuated by Casatti \& Castro (1998) and Carvalho et al. (2003a), Brazil is rich in environments with clear waters that facilitate the use of underwater observations. This fact, associated with the high fish species richness in the São Francisco, Xingu, Tapajós, Trombetas, and Tocantins drainages, demonstrates the great potential for new discoveries and calls attention to the fact that these rivers basins have an elevated degree of endemism and are under strong anthropic pressure, especially due to their high potential for hydroelectric use.

\section{Acknowledgements}

We greatly thank to Instituto Chico Mendes de Conservação da Biodiversidade (ICMBio) for the collect authorization (SISBIO $n^{\circ}$ 24259-2); Fundação Nacional do Índio (FUNAI) and United Nations Education, Scientific and Cultural Organization (UNESCO) for financial and field support to DGN in the Xingu Indigenous Park; staff of Pousada Mantega for field support to LNC in the ApiakáKayabi Indigenous Land; Virgínia Sanches Uieda for the critical reading of the manuscript and comments; Jansen Zuanon and Ricardo de Souza Rosa for the confirmation of the characiform species and the freshwater stingrays; anonymous referees for provided their time and valuable suggestions.

\section{References}

BAKER, J.A. \& FOSTER, S.A. 1994. Observations on a foraging association between two freshwater stream fishes. Ecol. Freshw. Fish 3:137-139. http://dx.doi.org/10.1111/j.1600-0633.1994.tb00115.x 
CARVALHO, L.N., ARRUDA, R. \& ZUANON, J. 2003a. Record of cleaning behavior by Platydoras costatus (Siluriformes: Doradidae) in the Amazon Basin, Brazil. Neotrop. Ichthyol. 1(2):137-139. http://dx.doi.org/10.1590/ S1679-62252003000200009

CARVALHO, M.R., LOVEJOY, N.R. \& ROSA, R.S. 2003b. Family Potamotrygonidae (river stingrays). In Check list of the freshwater fishes of South and Central America (R.E. Reis, S.O. Kullander \& C.J. Ferraris Junior, orgs.). Edipucrs, Porto Alegre, p.22-28.

CASATTI, L. \& CASTRO, R.M.C. 1998. A fish community of São Francisco River headwaters riffles, southeastern Brazil. Ichthyol. Explor. Freshwat. 9(3):229-242.

DARY, E.P. 2010. Composição e estrutura trófica das assembléias de peixes em um trecho do médio rio Teles Pires, Mato Grosso, Brasil. Dissertação de mestrado, Instituto Nacional de Pesquisas da Amazônia, Manaus.

GARRONE NETO, D.\& SAZIMA, I. 2009a. The more stirring the better: cichlid fishes associate with foraging potamotrygonid rays. Neotrop. Ichthyol. 7(3):499-501. http://dx.doi.org/10.1590/S167962252009000300018

GARRONE NETO, D.\& SAZIMA, I. 2009b. Stirring, charging, and picking: hunting tactics of potamotrygonid rays in the Upper Paraná River. Neotrop. Ichthyol. 7(1):113-116.

KRAJEWSKI, J.P. 2009. How do follower reef fishes find nuclear fishes? Environ. Biol. Fishes 86(3):379-387. http://dx.doi.org/10.1007/s10641009-9533-0

LASSO, C.A., RIAL, B.A. \& LASSO-ALCALA, O. 1996. Notes on the biology of the freshwater stingrays Paratrygon aiereba (Müller \& Henle, 1841) and Potamotrygon orbignyi (Castelnau, 1855) (Chondrichthyes: Potamotrygonidae) in Venezuelanllanos. Aqua 2(3):39-52.

LEITÃO, R.P., CARAMASCHI, E.P. \& ZUANON, J. 2007. Following food clouds: feeding association between a minute loricariid and a characidiin species in an Atlantic Forest stream, Southeastern Brazil. Neotrop. Ichthyol. 5(3):307-310.
LUKOSCHEK, V. \& McCORMICK, M.I. 2000. A review of multispecies foraging associations in fishes and their ecological significance. In 9th International Coral Reef Symposium. Bali, p.23-27.

MARTIN, P. \& BATESON, P. 1986. Measuring Behaviour-An Introductory Guide. Cambridge University Press, New York.

RINCON, G. 2006. Aspectos taxonômicos, alimentação e reprodução da raia de água doce Potamotrygon orbignyi (Castelnau) (Elasmobranchii: Potamotrygonidae) no Rio Paraná-Tocantins. Tese de doutorado, Universidade Estadual Paulista, Rio Claro.

SABINO, J. \& ZUANON, J. 1998. A stream fish assemblage in central Amazonia: distribution, activity patterns and feeding behavior. Ichthyol. Explor. Freshwat. 8(3):201-210.

SABINO, J. 1999. Comportamento de peixes em riachos: uma abordagem naturalística. In Ecologia de Peixes de Riachos (E.P. Caramaschi, R. Mazzoni\& P.R. Peres-Neto, eds.). Universidade Federal do Rio de Janeiro, Rio de Janeiro, p.183-208.

SAZIMA, C., KRAJEWSKI, J.P., BONALDO, R.M. \& SAZIMA, I. 2006. Nuclear-follower associations of reef fishes and other animals at an oceanic archipelago. Environ. Biol. Fishes 80:351-361. http://dx.doi. org/10.1007/s10641-006-9123-3

SAZIMA, I. 1986. Similarities in feeding behaviour between some marine and freshwater fishes in two tropical communities. J. Fish Biol. 29:53-65. http://dx.doi.org/10.1111/j.1095-8649.1986.tb04926.x

STRAND, S. 1988. Following behavior: interspecific foraging associations among Gulf of California reef fishes. Copeia 2:351-357. http://dx.doi. org/10.2307/1445875

TERESA, F.B. \& CARVALHO, F.R. 2008. Feeding association between benthic and nektonic Neotropical stream fishes. Neotrop. Ichthyol. 6(1):109-111. http://dx.doi.org/10.1590/S1679-62252008000100013

TERESA, F.B., ROMERO, R.M., CASATTI, L. \& SABINO, J. 2011. Habitat simplification affects nuclear-follower foraging association among stream fishes. Neotrop. Ichthyol. 9(1):121-126. http://dx.doi.org/10.1590/S167962252011005000009 